Karolina Kulas

(iD) https://orcid.org/0000-0002-3438-7077

Szkoła Doktorska KUL

Katolicki Uniwersytet Lubelski Jana Pawła II

20-950 Lublin, Aleje Raclawickie 14

karolina2906@student.kul.lublin.pl

https://doi.org/10.18778/8220-520-6.15

\title{
DUBBING W POLSCE, ROSJI I BUŁGARII JAKO OBIEKT DYSKURSU MEDIALNEGO - ANALIZA PORÓWNAWCZA
}

\section{Dubbing in Poland, Russia, and Bulgaria as an object of media discourse: a comparative analysis}

\author{
Аубляж в Польше, России и Болгарии как объект меАийного \\ Аискурса - сравнительный анализ
}

\begin{abstract}
Streszczenie
Badanie dubbingu w dyskursie medialnym w Polsce, Rosji i w Bułgarii, które było przedmiotem niniejszych badań, miało na celu wskazanie pozycji i perspektyw jego rozwoju w krajach, gdzie oficjalnie dominuje wersja lektorska. Materiał badawczy stanowiły artykuły internetowe, publikacje badaczy przekładu filmowego oraz wpisy na forach poświęconych tematyce dubbingu interlingwalnego. Analiza tekstów wykazała, że dubbing w analizowanych krajach ma podobny zasięg oddziaływania - odnosi się w głównej mierze do przekładu tekstów animowanych. Obok szeregu zalet przypisywanych dubbingowi wskazano na wiele wad, niesprzyjających umocnieniu jego pozycji w ww. krajach. Są to m.in. ograniczenie dostępu do wersji oryginalnej, możliwości manipulacji widzami, kosztochłonność procesu tłumaczenia. Te ograniczenia pozwalają wysnuć wniosek, że dubbing w najbliższej przyszłości nie zdominuje rynku tłumaczeń audiowizualnych w tych krajach.
\end{abstract}

\section{Summary}

The study of dubbing in the media discourse in Poland, Russia, and Bulgaria, which was the subject of this research, was aimed at indicating the position and prospects of its development in countries where the voice-over technique prevails. The research material consisted of online articles, publications of film translation researchers, and posts on 
forums devoted to interlingual dubbing. The analysis of the texts showed that dubbing in the analyzed countries has a similar range of impact: it mainly relates to the translation of animated productions. In addition to a number of advantages of dubbing, a number of disadvantages were observed, which do not help strengthen its position in the studied countries. These include limiting access to the original version, the possibility of manipulating the audience, the cost-intensive translation process These limitations lead to the conclusion that dubbing will not dominate the audio-visual translation market in these countries in the near future.

\section{Резюме}

Изучение Аубцяжа в медиадискурсе Польши, России и Болгарии, которое стало предметом Аанного исследования, было направлено на указание положения и перспектив его развития в странах, где версия закадрового озвучивания является официально Аоминирующей. Материал исследования состоял из статей в Интернете, публикаций исследователей перевода фильмов и сообщений на форумах, посвященных межъязыковому дубляжу. Анализ текстов показац, что дубляж в анализируемых странах имеет аналогичный диапазон воздействия - в основном это касается перевода анимационных текстов в вышеупомянутых странах. Они вкмючают ограничение Аоступа к оригинальной версии, возможность манипулирования зрителями, затратность процесса перевода. Эти ограничения позволяют сАелать вывоА, что Аубляж не будет Аоминировать на рынке аудиовизуацьного перевода в этих странах в ближайшем будущем.

Słowa kluczowe: tłumaczenie audiowizualne, dubbing, szeptanka, dyskurs, napisy, media.

Keywords: audio-visual translation, dubbing, whispering, discourse, subtitles, media.

Кмючевые слова: аудиовизуальный перевоА, Аубляж, войсовер, Аискурс, субтитры, массмеАия.

Druga połowa XX w. zmieniła preferencje w zakresie sposobów obcowania człowieka z kulturą. Nastąpiło przesunięcie punktu ciężkości z zainteresowania książką, literaturą na zainteresowanie produkcjami filmowymi i technikami tłumaczenia audiowizualnego. W rezultacie przekład filmowy na przełomie XIX i XX w. stał się ważkim medium komunikacji interkulturowej z uwagi na masowy charakter produkcji filmowych, podlegających takiemu przekładowi (Mocarz-Kleindienst, 2014, 173), mimo iż kino, zdaniem Maryli Hopfinger, wrastało w kulturę XX w. opornie i pierwotnie było ono uważane za „spektakularny przejaw barbarzyństwa" (Hopfinger 1997, cyt. za: Mocarz-Kleindienst, 2014, 174). Obecnie jest to najszybciej rozwijająca się odmiana przekładu, zorientowana na środki masowego przekazu tj. Internet, telewizja oraz kino (Tomaszkiewicz, 2006, 97). Wśród dostępnej literatury przedmiotu w zakresie tłumaczeń audiowizualnych nie brakuje tej poświęconej próbie porównania i wartościowania 
technik stosowanych przez tłumaczy filmowych. Wśród nich należy wymienić publikacje Agaty Hołobut i Moniki Woźniak (2017), Agnieszki Szarkowskiej (2008), jak też zagraniczne pozycje m.in. Dirka Delabastity (1989) czy Pereza Gonzaleza (2014). Przyczyn dyskusji wokół dubbingu należy upatrywać już na etapie powstawania prac nad teorią tłumaczenia audiowizualnego i jego odmian. Podział tłumaczeń audiowizualnych ( $w$ tym filmowych) zostanie tu ograniczony do wskazania jedynie głównych jego odmian tj.: wersji lektorskiej, napisów na dole ekranu oraz dubbingu. Dokonując analizy literatury przedmiotu poświęconej tematyce konkretnych technik tłumaczenia filmowego, ich wartościowania, prób ich porównania, można zauważyć duże zainteresowanie badaczy dubbingiem interlingwalnym.

Na początek warto przytoczyć definicję dubbingu. Podążając za Teresą Tomaszkiewicz: „dubbing jest to proces, w wyniku którego cała ścieżka dźwiękowa oryginalnego filmu lub programu telewizyjnego jest zastąpiona nową ścieżką z nagraną nową wersją językową" (Tomaszkiewicz 2006, cyt. za: Hołobut, 2017, 22).

Ożywiona dyskusja na temat roli dubbingu we współczesnym przekładzie filmowym, jego jakości, skutków jego zastosowania i rokowań znajduje także odzwierciedlenie $\mathrm{w}$ wielu pracach naukowych poświęconych tłumaczeniom audiowizualnym na całym świecie, $\mathrm{w}$ szczególności $\mathrm{w}$ krajach $\mathrm{z}$ dubbingiem jako techniką w roli głównej. Są to np. Translation and Mass-Communication: Film and T.V.-Translation as Evidence of Cultural Dynamics (Delabastita, 1989, 193-218), Audiovisual Translation Theories, Methods and Issues (Perez Gonzalez, 2014), artykuł Wojciecha Oleksiaka pt. Subtitles, Dubbing or Voice-over? Discuss (culture. $\mathrm{pl} / \mathrm{en}$ ). Prace naukowe uzupełniają dyskusje, toczące się obecnie w głównej mierze w Internecie, jak np. dyskusja podczas corocznego Europejskiego Forum Filmowego w Berlinie Berlinale na temat tworzenia napisów i dubbingu (https:// ec.europa.eu/). Warto też wspomnieć o wywiadzie ze Zbigniewem Dolnym, w którym opowiada on o szkole polskiego dubbingu z perspektywy nie tylko badacza, ale przede wszystkim kinomana (http://polski-dubbing.pl/). Dubbing jest przedmiotem dyskusji badaczy i miłośników kina na całym świecie. Na różnych forach internetowych można przeczytać o sukcesie debiutu Lidii Wysockiej, która zebrała doskonałe recenzje, grając w filmie Siostra Marta jest Szpiegiem, a także o polskim dubbingu przedwojennym, który zdaniem Zbigniewa Dolnego był „najlepszy na świecie” (http://polski-dubbing.pl/).

Taki stan rzeczy czyni zasadnym podejmowanie kolejnych prób opisu i prób oceny pozycji dubbingu i perspektyw jego rozwoju zwłaszcza w tych krajach, gdzie jego pozycja nie jest tak ugruntowana, jak ma to miejsce np. w krajach Europy Zachodniej (Niemczech, Włoszech itd.), ale jego obecność jest zauważalna. Głównym celem niniejszych badań jest analiza pozycji i perspektyw rozwoju dubbingu w trzech krajach słowiańskich: Polsce, Rosji i Bułgarii, w których aktualnie dominuje wersja lektorska. Podjęta przez nas próba opisu i oceny zjawiska dubbingu zostanie przeprowadzona na podstawie analizy materiału badawczego: 
tekstów, wywiadów oraz dyskusji w Internecie, prasie i telewizji, które inicjują nie tylko badacze przekładu filmowego, ale również miłośnicy kina oraz zwolennicy i przeciwnicy dubbingu.

W wymienionych krajach dubbing występuje w przekładzie filmów animowanych oraz w kanałach telewizyjnych dedykowanych najmłodszym widzom. Zyskuje on tam jednak coraz większą popularność za sprawą rosnącej liczby filmów animowanych produkcji zagranicznych, także dzięki powstaniu szkół kształcących przyszłych tłumaczy audiowizualnych, aktorów dubbingujących, lektorów, adiustatorów i dialogistów. Dubbing jest odmianą tłumaczenia audiowizualnego dedykowaną dzieciom i osobom mającym problem z czytaniem. Ponadto platformy streamingowe, tj. Netflix, YouTube, HBO GO, Ipla, Player, Spotify, prześcigają się w ofercie filmów i coraz częściej wymagają od wytwórni filmowych filmów z dubbingiem.

Dubbing jest najbardziej złożoną odmianą tłumaczenia audiowizualnego ze względu na znaczną liczbę osób zaangażowanych w proces powstawania wersji językowej dubbingu. Tłumaczenie warstwy tekstowej jest tylko jednym z elementów wieloetapowego procesu. W przeciwieństwie do napisów czy też wersji lektorskiej wysoka jakość tłumaczenia dialogów nie przesądza o dobrej jakości wersji językowej dubbingu jako finalnego produktu, gdyż thumacz przygotowuje jedynie surowy tekst, który poddany jest licznym obróbkom adiustatora, dialogisty i aktora dubbingującego. Szereg transformacji warstwy tekstowej thumacza wymusza konieczność zastosowania synchronizacji, którą Frederic Chaume scharakteryzował jako ,jedną z cech opracowania dubbingowego, polegającą na dostosowaniu translatu do ruchów aparatu mowy oraz ciała aktorów i aktorek przedstawionych na ekranie oraz na dostosowaniu tłumaczonych wypowiedzi i pauz do tekstu wyjściowego" (Chaume 2004, cyt za: Hołobut, 2017, 23). Powyższe przesłanki tłumaczą dyskursywne podejście do kwestii dubbingu.

Aby lepiej wniknąć w problematykę badawczą, zasadne wydaje się przedstawienie krótkiego rysu historycznego rozwoju tej techniki we wspomnianych krajach.

Historia polskiego dubbingu sięga lat 30 . XX w. Pierwsze filmy zdubbingowano tuż przed II wojną światową. Dubbing był w okresie międzywojennym pożądany, gdyż grał znaczącą rolę z punktu widzenia społecznego i narodowego. Budował tożsamość narodową. Należy tu wymienić polski dubbing amerykańskiego musicalu Parada Paramountu z 1931 r. oraz niemieckiego dramatu Ulubieniec Bogów z roku 1931.

Warto też wspomnieć o starannie wykonanym dubbingu brytyjskiego dramatu wojennego z 1935 r. I was a spy, który w polskiej wersji występuje jako Siostra Marta jest szpiegiem.

Po wojnie powstał w Łodzi Wydział Dubbingu przekształcony w 1955 r. w Warszawskie Studio Opracowań Dialogowych. Dubbingowano w tym czasie filmy i seriale telewizyjne, a także filmy dla dzieci. Ze względu na doskonałą jakość 
wykonania i wspaniałą obsadę nie można pominąć polskiego dubbingu rosyjskiej powieści Lwa Tołstoja, w którym głosu Annie Kareninie użyczyła Aleksandra Śląska, a Andrzej Łapicki - Aleksemu Wrońskiemu. Film ten był zaprezentowany na otwarciu Dni Filmu Radzieckiego. Złoty wiek polskiego dubbingu przypadał na lata 60.-80. XX w. Ponad jedna trzecia zagranicznych filmów była w tym czasie dubbingowana. Polski dubbing tego okresu cechował nienaganny styl, staranna dykcja aż do kryzysu lat osiemdziesiątych XX w.

$\mathrm{Z}$ kolei dubbing rosyjskojęzyczny był od samego początku narzędziem politycznej cenzury. Pierwszym filmem, jaki zdubbingowano w ZSRR, był Niewidzialny człowiek [Человек Невидимка] w 1933 r., jednak film ukazał się w ZSRR dwa lata później w 1935 r. Do roku 1950 filmy z dubbingiem były rzadkością ze względu na Wielką Wojnę Ojczyźnianą. Mistrzem drugiego planu w rosyjskim dubbingu była aktorka układająca dialogi (aкmpuca yкıадчuщa), nadająca im osobne brzmienie, gdyż zadaniem aktorów w rosyjskim dubbingu było stworzenie nowego bohatera, o typowej dla niego intonacji, który nie kopiuje, lecz kreuje własnego bohatera (https://www.timeout.ru/). W latach 1947-1991 w trakcie trwania zimnej wojny rosyjski dubbing był narzędziem politycznej propagandy. W dubbingu filmów radzieckich pojawiał się niezapowiedziany głos aktora, który tłumaczył sytuacje w filmie, zgodnie z obowiązującą doktryną polityczną.

Dubbing w Bułgarii ściśle wiąże się z powstaniem Studia filmów fabularnych w 1950 r. oraz Bułgarskiej Telewizji Narodowej (БНТ) w 1959 r. Rozwój dubbingu w Bułgarii rozpoczął się w roku 1930, gdy początkowo Teatr Niszowy, a następnie Teatr Współczesny oraz siedem kolejnych kin w Sofii rozpoczęło projekcję filmów dźwiękowych. Do roku 1974 w Bułgarii był tylko jeden kanał telewizyjny, rozwój dubbingu był zatem wtedy znikomy. Przemiany polityczne w Bułgarii po 1989 r. zaowocowały pojawieniem się telewizji prywatnej, która zaczęła emitować swoje programy już w 1993 r. Liczba kanałów regionalnych i specjalistycznych rosła w szybkim tempie, stąd zrodziła się potrzeba wykonywania tłumaczeń szybko i w dużych ilościach.

Dyskusja i polemika tocząca się w środkach masowego przekazu na temat zalet i wad dubbingu, tj. w krajach słowiańskich, trwa nieprzerwanie od 2. pol. $\mathrm{XX}$ w. Jaki jest obecny stosunek do dubbingu w uwzględnianych przez nas krajach? Wśród zalet polskiego dubbingu wymienia się doskonałą obsadę aktorską w osobach native speakerów, naturalnie brzmiące dialogi po licznych zabiegach translatorskich, brak konieczności czytania napisów czy też wsłuchiwania się w głos lektora, jak to jest w przypadku voice-over. Swojskość i naturalne brzmienie dialogów autorstwa Bartosza Wierzbięty w polskim dubbingu filmu Shrek sprawia, że polski dubbing zyskał na wartości za sprawą samej warstwy dialogowej Wierzbięty, nie tylko doskonałej obsady aktorskiej. Hołobut przypisuje dubbingowi dodatkowo funkcje edukacyjne i integracyjne (Hołobut, 2017, 23). Wśród wad dubbingu wymienia się brak dostępu do oryginalnej ścieżki dźwiękowej filmu, dostęp do wersji filmu wyłącznie po gruntownej synchronizacji i zastoso- 
waniu strategii obróbki tekstu, najwyższe koszty jego produkcji względem pozostałych odmian przekładu filmowego, nadmierną kondensację warstwy tekstowej filmu, niekiedy nieprzemyślaną obsadę aktorską, a także zaburzoną synchronizację w filmie. Ponadto wśród wielu polskich widzów panuje przekonanie, że „dla świadomego widza odebranie oryginalnej ścieżki dźwiękowej stanowi po prostu zubażanie filmu" (https://natemat.pl/).

Z kolei zdaniem bułgarskich badaczy, dubbing, w szczególności interlingwalny, był i jest $\mathrm{w}$ dalszym ciągu narzędziem formowania świadomości narodowej. Za przykłady podają oni dubbingowane produkcje filmowe we Włoszech, Niemczech, Hiszpanii, a także w Hiszpanii Ávila-Cabrera nazywa dubbing pułapką, jaką stosuje kino, by uczynić dany film zrozumiałym dla jak najszerszej grupy odbiorców (https://www.researchgate.net/). Wszystko za sprawą nadmiernej ingerencji w treść oryginału oraz zastosowania synchronizacji poprzez redukcję, pominięcie i kondensację warstwy tekstowej (Аамбова, Мичев, 2014, 5). Naukowcy z Uniwersytetu w Sofii wymieniają jednak i zalety dubbingu, zaliczając do nich możliwość śledzenia akcji i dialogów bez konieczności odwracania uwagi od obrazu, co czyni odbiór filmu bardziej naturalnym. Dzięki dubbingowi widz może zwrócić uwagę na pozajęzykowe elementy narracji filmu, tj. gesty, mimikę, wygląd postaci, grę aktorską, efekty kinowe i nie tylko. Aktorzy dubbingujący - native speakerzy dzięki zastosowanym strategiom przekładu i intonacji czynią fabułę filmu bardziej przystępną. Dubbing filmów animowanych to jedyny sposób na prezentację zagranicznych filmów animowanych dzieciom. Ponadto, umożliwia on odbiór filmów zagranicznych przez osoby, które nie znają języka obcego lub mają problemy z czytaniem i widzeniem. Wśród bułgarskich badaczy panuje zgodne przekonanie, iż dubbing pozwala wzmocnić kulturę języka ojczystego. Co więcej, umożliwia on dostęp do filmów osobom dotkniętych problemem analfabetyzmu (https://bulgarianhistory.org/).

Od ostatniej dekady XX w. do dziś liczba filmów emitowanych na małym ekranie w Bułgarii wzrosła diametralnie. Tylko Bułgarska Telewizja Narodowa od pół roku emituje łącznie 920 godzin (czyli około 5 godzin dziennie) zagranicznego programu filmowego: filmy fabularne, seriale, filmy dziecięce i animowane, filmy dokumentalne. Zwiększony popyt na tłumaczenie filmowe na rynku bułgarskim po 1993 r. rodzi kwestię zarówno dostępnego wyposażenia technicznego, jak i jakości samego tłumaczenia, co zakłada potrzebę przeszkolenia tłumaczy i redaktorów, którzy mogą zaoferować tę konkretną usługę w sposób jakościowy i terminowy. Od 2007 r. dubbing zaczyna ustępować miejsca napisom. Jest to skutek przystąpienia Bułgarii do Unii Europejskiej. Zakłada ona nauczanie języka angielskiego z filmów oraz edukację w zakresie języka angielskiego jako powszechnie obowiązującego.

W Bułgarii rodzaj tłumaczenia zależy od specyfiki danego kanału. Kanały telewizyjne, których programy są nadawane w różnych krajach, używają napisów. Tak jest na przykład w przypadku AXN, AXN Crime i innych. W przypadku ka- 
nałów, które oferują zarówno filmy z dubbingiem, jak i z napisami, głównym kryterium decydującym o wyborze typu tłumaczenia audiowizualnego jest rodzaj filmu. Seria jest prawie w całości dubbingowana, podczas gdy napisy są zwykle używane w pełnometrażowych filmach, które nie są emitowane w seriach. Innym ważnym kryterium przy wyborze rodzaju tłumaczenia audiowizualnego w Bułgarii jest adresat. Dubbingowane są jedynie filmy przeznaczone dla widzów dziecięcych, a także tzw. filmy rodzinne (https://bulgarianhistory.org). Pozycja dubbingu w Bułgarii jest zatem niewątpliwie zagrożona. Krassimir Kutsuparov - reżyser dubbingu oraz bułgarski aktor traktuje dubbing jako spoiwo dla narodu bułgarskiego i ubolewa nad brakiem wewnętrznych regulacji prawnych w tym zakresie. Ponadto bardzo klarownie thumaczy, dlaczego dubbing jest w Niemczech dominującą odmianą thumaczenia audiowizualnego. Jego zdaniem Niemcy są w pełni świadomi zagrożenia płynącego z nadawania amerykańskich filmów z napisami. Dlatego - jego zdaniem - dubbingują oni filmy obcojęzyczne bez względu na to, jak drogi, wolniejszy i bardziej skomplikowany jest ten proces. Zdaniem Kutsuparova Niemcy w ten sposób udowadniają, że skoro dubbing jest preferowany przez widzów, musi być on wykonany precyzyjnie i prezentować bardzo wysoką jakość.

Zdaniem rosyjskiego krytyka filmowego Aleksieja Miedwiediewa wybór techniki przekładu filmowego uzależniony jest od nastawienia psychicznego narodu, stopnia rozwoju kultury kina, a także możliwości szybkiego czytania tekstu. Miedwiediew wskazuje szeptankę jako ulubioną, głęboko zakorzenioną odmianę tłumaczenia audiowizualnego u Rosjan. Stwierdza, że w Rosji zakorzeniła się subkultura przekładu pirackiego z monotonną, często także ironiczną i zabawną szeptanką. Podkreśla, że podczas gdy w innych krajach voice-over traktowany jest jako „współczesny przejaw barbarzyństwa”, to w Rosji ta forma dwugłosu (męskiego - dla ról męskich i żeńskiego - dla ról żeńskich) jest dobrze przyjętym zwyczajem (http:/ / www.lookatme.ru). To właśnie voice-over jest dominującą odmianą tłumaczenia filmowego w Rosji. Miedwiediew podkreśla, że wersja z napisami zniechęca Rosjan, co wynika z braku nawyku szybkiego czytania. Mimo dużej dostępności w latach 90. filmów w wersji z napisami ta odmiana thumaczenia audiowizualnego nie zyskała aprobaty rosyjskiego społeczeństwa (http:// www.lookatme.ru/). W odniesieniu do dubbingu w Rosji stosuje się następująca nomenklaturę: дубляж, дублирование, дублированный перевод. Bywa także utożsamiany z odmianą wersji lektorskiej, która występuje pod hasłami: закадровыц перевод, озвучивание, закадровое озвучивание или войсовер. Nazewnictwo technik tłumaczenia filmowego w Rosji jest zatem bardzo bogate i należy uważać, czy $\mathrm{w}$ tekstach rosyjskojęzycznych, gdy jest mowa o dubbingu, autor nie miał raczej na myśli wersji filmu z lektorem.

Powszechna globalizacja, cyfryzacja, przewaga języka angielskiego nad innymi językami i chęć dotarcia do jak największej grupy odbiorców z jednej strony skłania do zastosowania szeptanki lub wersji z napisami w przekładzie filmów amerykańskich na języki europejskie. Z drugiej strony w krajach Europy Zachodniej 
dominuje dubbing jako narodowa forma wyrazu zagranicznej produkcji filmowej. Sytuację dubbingu w krajach Unii Europejskiej reguluje dodatkowo polityka medialna i audiowizualna UE, która w ramach programu „Kreatywna Europa” realizowanego w latach 2014-2020 stawia sobie za cel wspieranie poprzez promocję różnorodności kulturowej i językowej krajów członkowskich z jednej strony i sprostanie światowej globalizacji i cyfryzacji czy też oczekiwaniom agencji filmowych, firm, które mają trudności z dotarciem do społeczeństw nie posługujących się biegle językiem angielskim $\mathrm{z}$ drugiej strony. Czynnik finansowy w wielu przypadkach decyduje o wyborze tańszej, od lat wykorzystywanej i dobrze przyjętej w Polsce, Bułgarii i Rosji wersji lektorskiej. Ponadto dobór aktorów dubbingujących nie może być przypadkowy, o czym można się szybko przekonać, podstawiając w miejsce Jerzego Stuhra wcielającego się w rolę słynnego Shreka Krystynę Czubównę. Zły wybór aktorski może zaważyć na losach całego dubbingu bardziej niż nieprofesjonalne tłumaczenie warstwy tekstowej filmu. Wybór widzów między powszechną i lubianą w Polsce i Bułgarii wersją lektorską a dubbingiem wydaje się przesądzony. Wszystko za sprawą zarówno wysokich kosztów długiego procesu, jakim jest przygotowywanie dubbingu, jak też jego złej jakości, niekiedy braku profesjonalnej obsady aktorskiej, zaburzonej synchronizacji czy też nadmiernej kondensacji treści oryginału w przekładzie dubbingu. Kinoman Zbigniew Dolny, badacz dubbingu, stwierdził w wywiadzie, iż polski dubbing „zabił” brak środków na jego realizację (http://polski-dubbing.pl/).

Mimo iż zainteresowanie dubbingiem w całej Europie nie słabnie, jego los w Polsce, Rosji i Bułgarii jest obiektywnie przesądzony: nie jest on w stanie wyprzeć ani wersji lektorskiej, ani napisowej. Wprawdzie w studiach dubbingu w Polsce, Bułgarii i Rosji sztaby specjalistów opracowują wersję językową filmów, angażowani są świetni dialogiści, np. Bartosz Wierzbięta, którego pełne humoru dialogi przyciągają do kin rzesze publiczności, ze względu na swojski i przyjemny w odbiorze język i prosty przekaz, pełen komizmu. Są to jednak wysiłki podejmowane dla ograniczonego kręgu odbiorców - wyłącznie filmów animowanych. Otwartość na kulturę amerykańską, polityka medialna i audiowizualna Unii Europejskiej względem Polski i Bułgarii, a w szczególności „Program Kreatywna Europa" przewidziany na lata 2014-2020, zakłada stworzenie jednolitego europejskiego rynku usług audiowizualnych (https://www.europarl.europa.eu/). Taka strategia ma oswoić język angielski wśród Europejczyków, sprostać wymaganiom globalizacji i cyfryzacji, a także zaspokoić potrzebę dotarcia zagranicznych agencji filmowych i platform streamingowych do społeczeństwa odmiennego językowo i kulturowo.

Dubbing staje się przywilejem krajów wysoko rozwiniętych. W takich krajach jak np. Włochy dubbing ma bardzo długą tradycję i niejako cel edukacyjny (Hołobut, 2017). „Na zachodzie dubbinguje się dosłownie wszystko” - można przeczytać na forum internetowym poświęconym dubbingowi w Europie (https://naekranie.pl/). Specyfika dubbingu, sytuacja polityczna w wybranych 
krajach słowiańskich, ukształtowane preferencje widzów oraz duże koszty ponoszone przy tworzeniu dubbingu skutkują wyparciem dubbingu na rzecz wersji $\mathrm{z}$ napisami oraz voice-over w Rosji, Polsce oraz Bułgarii.

\section{Bibliografia}

Delabastita, D. (1989). Translation and Mass-Communication: Film and T.V. - Translation as Evidence of Cultural Dynamics. Babel, 193-218.

Dubbing $w$ Polsce i $w$ Europie - jak to dziata?. https://naekranie.pl/aktualnosci/dubbing-w-polsce-i-w-europie-jak-to-dziala (dostęp: 13.11.2020).

Europejskie Forum Filmowe Berlinale. https://ec.europa.eu/digital-single-market/en/ news/european-film-forum-discussed-subtitling-and-dubbing-berlinale (dostęp: 13.11.2020).

First Insights into the combination of dubbing and subtitling as L2 didactic tools. https:// www.researchgate.net/publication/257944948_First Insights into the combination_of_dubbing_and_subtitling_as_L2_didactic_tools (dostęp: 14.11.2020).

Historia butgarskiego kina. https://bulgarianhistory.org/istoriq-na-bulgarskoto-kino/ (dostęp: 12.11.2020).

Hołobut, A., Woźniak, M. (2017). Historia na ekranie. Gatunek filmowy a przekład audiowizualny. Kraków: Wyd. UJ.

Mocarz-Kleindienst, M. (2014). Miejsce przekładu filmowego $w$ badaniach translatorycznych. Rocznik Przekładoznawczy, 9, 173-180.

Określenie "polska szkota dubbingu nie wzięło się znikąd”. http://polski-dubbing.pl/fo$\mathrm{rum} /$ viewtopic.php? $\mathrm{f}=9 \& \mathrm{t}=826$ (dostęp: 13.11 .2020$)$.

Pérez González, L. (2014). Audiovisual Translation. Theories,Methods and Issues. London: Routledge.

Polityka medialna i audiowizualna. https://www.europarl.europa.eu/factsheets/pl/sheet/138/polityka-audiowizualna-i-medialna (dostęp: 14.11.2020).

Polityka medialna i audiowizualna. Noty tematyczne o Unii Europejskiej. https://www.europarl.europa.eu/factsheets/pl/sheet/138/audiovisual-and-media-policy (dostęp: 9.11.2020).

Snell-Hornby, M. (1988). Translation Studies. An Integrated Approach. Amsterdam-Philadelphia. John Benjamins Publishing Company.

Szarkowska, A. (2008). Przektad audiowizualny w Polsce - perspektywy i wyzwania. Przekładaniec, $\mathrm{nr} 20$.

Tomaszkiewicz, T. ( 2006). Przekład audiowizualny. Warszawa: Wyd. Naukowe PWN.

85 ^ет за кадром: краткая история русского дубляжа. https://www.timeout.ru/ (dostęp: 13.11.2020)

Почему в России таклюят дубляж. http://www.lookatme. ru/mag/how-to/inspirationhowitworks/208481-dubbing-x-russia-love (dostęp: 9.11.2020).

За дублажа и субтитрирането в българския телевизионен фиммов ефир. http:// eprints.nbu.bg/1913/ (dostęp: 9.11.2020).

Нлколко думи за дублажк. https://artizanin.com/a-few-words-about/4/ (dostęp: 9.11.2020). 